\title{
A demographic history of a population of howler monkeys (Alouatta palliata) living in a fragmented landscape in Mexico
}

\author{
Jurgi Cristóbal Azkarate ${ }^{\text {Corresp., }}{ }^{1}$, Jacob Charles Dunn ${ }^{\text {Corresp.. }}{ }^{1,2}$, Cristina Domingo Balcells ${ }^{3}$, Joaquim Veà Baró ${ }^{4}$ \\ ${ }^{1}$ Division of Biological Anthropology, University of Cambridge, Cambridge, United Kingdom \\ 2 Animal and Environment Research Group, Anglia Ruskin University, Cambridge, United Kingdom \\ 3 Instituto de Biología, Universidad Nacional Autónoma de México, Mexico City, Mexico \\ ${ }^{4}$ Centre Especial de Recerca en Primats, Facultat de Psicologia, Universitat de Barcelona, Barcelona, Spain \\ Corresponding Authors: Jurgi Cristóbal Azkarate, Jacob Charles Dunn \\ Email address: jca40@cam.ac.uk, jcd54@cam.ac.uk
}

Long-term field studies are critical for our understanding of animal life history and the processes driving changes in demography. Here, we present long-term demographic data for the northernmost population of mantled howler monkeys (Alouatta palliata) residing in a highly anthropogenically fragmented landscape in Los Tuxtlas, Mexico. We carried out 454 monthly group visits to 10 groups of mantled howler monkeys between 2000 and 2011. The population remained relatively stable over the 11-year study period, with an overall increase in the total number of individuals. Birth rates and inter-birth intervals were comparable to those of howler monkeys at non-fragmented sites, suggesting that living in a fragmented landscape did not affect the reproductive output of our study population. Moreover, despite the landscape, dispersal events were commonplace, including many secondary dispersals (individuals emigrating from groups that they had previously immigrated into). Finally, we found a marked effect of seasonality on the dynamics of our study population. In particular, the period of lowest temperatures and resource scarcity between November and March was associated with higher mortality and reproductive inhibition, while the period of resource abundance between April and May was associated with the majority of conceptions and weaning of offspring. This, in turn, could be influencing dispersal patterns in our study area, as male howler monkeys seem to time some of their immigrations into new groups to coincide with the start of the period of higher fertility, while females preferentially joined new groups several months before the onset of this period. These data have important implications for the conservation and management of howler monkeys in fragmented landscapes, as well as for our understanding of the effect of seasonality over howler monkey dispersal, reproduction and survival. 
1 A demographic history of a population of howler monkeys (Alouatta palliata) living in a

2 fragmented landscape in Mexico

3

4 Jurgi Cristóbal-Azkarate ${ }^{1, *}$, Jacob C. Dunn ${ }^{1,2, *}$, Cristina Domingo-Balcells ${ }^{3}$, Joaquim Vea-Baro ${ }^{4}$

$8{ }^{1}$ Division of Biological Anthropology, University of Cambridge, Pembroke Street, Cambridge, 9 CB2 3QY, UK

$10{ }^{2}$ Animal and Environment Research Group, Anglia Ruskin University, East Road, Cambridge, 11 CB1 1PT, UK

12 Instituto de Biología, Universidad Nacional Autónoma de México, Tercer Circuito s/n, Ciudad

13 Universitaria, Copilco, Coyoacán. A.P. 70-153 México, D.F., México

$14{ }^{4}$ Centre Especial de Recerca en Primats, Facultat de Psicologia, Universitat de Barcelona, Valle 15 de Hebron 171, Barcelona, 08035, España.

$18{ }^{*}$ Corresponding Authors:

19 Jacob C. Dunn and Jurgi Cristóbal-Azkarate

20 Division of Biological Anthropology, University of Cambridge, Pembroke Street, Cambridge, 21 CB2 3QY, UK; Tel: (+44) 01223 335459; Tel: (+44) 01223 35459:

22 Email: jcd54@cam.ac.uk (JD),jca40@cam.ac.uk (JCA); Fax. +52 (228) 8108263 


\section{ABSTRACT}

26 Long-term field studies are critical for our understanding of animal life history and the processes

27 driving changes in demography. Here, we present long-term demographic data for the

28 northernmost population of mantled howler monkeys (Alouatta palliata) residing in a highly

29 anthropogenically fragmented landscape in Los Tuxtlas, Mexico. We carried out 454 monthly

30 group visits to 10 groups of mantled howler monkeys between 2000 and 2011. The population

31 remained relatively stable over the 11-year study period, with an overall increase in the total

32 number of individuals. Birth rates and inter-birth intervals were comparable to those of howler

33 monkeys at non-fragmented sites, suggesting that living in a fragmented landscape did not affect

34 the reproductive output of our study population. Moreover, despite the landscape, dispersal

35 events were commonplace, including many secondary dispersals (individuals emigrating from

36 groups that they had previously immigrated into). Finally, we found a marked effect of

37 seasonality on the dynamics of our study population. In particular, the period of lowest

38 temperatures and resource scarcity between November and March was associated with higher

39 mortality and reproductive inhibition, while the period of resource abundance between April and

40 May was associated with the majority of conceptions and weaning of offspring. This, in turn,

41 could be influencing dispersal patterns in our study area, as male howler monkeys seem to time

42 some of their immigrations into new groups to coincide with the start of the period of higher

43 fertility, while females preferentially joined new groups several months before the onset of this

44 period. These data have important implications for the conservation and management of howler

45 monkeys in fragmented landscapes, as well as for our understanding of the effect of seasonality

46 over howler monkey dispersal, reproduction and survival. 


\section{INTRODUCTION}

Long-term field studies of primates, i.e., studies that cover at least an important proportion of individual life cycles, are critical for our understanding of life history and the processes driving changes in demography (Kappeler \& Watts, 2012). However, field studies that have lasted long enough to provide data spanning several generations have only been carried out on a very small number of primate species (Kappeler \& Watts, 2012), and the long-term studies that do exist are usually limited to one or a handful of sites across the species' distribution. Given that demographic patterns are contingent on local climate and vegetation, a comprehensive understanding of the factors determining dispersal processes, mortality and fertility of primates requires long-term studies to be conducted not only in different taxa, but also in different landscapes and locations. Such studies are particularly important in modified habitats, where monitoring demographic parameters in threatened populations may be critical for primate conservation.

Long-term data on howler monkey (Alouatta spp.) demography is limited to studies of

64 red howler monkeys in Venezuela (A. arctoidea) (Crockett \& Rudran, 1987; Rudran \&

65 Fernandez-Duque, 2003), mantled howler monkeys in Panama (A. palliata aequatorialis)

66 (Milton, 1982, 1990, 1996) and Costa Rica (A. p. palliata) (Glander, 1992; Clarke et al., 2002;

67 Zucker \& Clarke, 2003; Clarke \& Glander, 2010), black and gold howler monkeys (A. caraya) in

68 Argentina (Kowalewski \& Zunino, 2004; Zunino et al., 2007), and Central American black

69 howler monkeys (A. pigra) in Mexico (Dias et al., 2015). 

monkeys (Alouatta palliata mexicana) residing in a highly fragmented landscape in the Los

72 Tuxtlas Biosphere Reserve, Mexico. Despite howler monkeys having been studied since the

73 1980s in Los Tuxtlas (Cristóbal-Azkarate \& Dunn, 2013), our knowledge of reproduction, based on indirect evidence from single population censuses and anecdotal observations (Estrada \& Coates-Estrada, 1996; Cristóbal-Azkarate, Dias \& Veà, 2004; Cristóbal-Azkarate et al., 2005). The motivation for this study was twofold. Firstly, we wanted to analyse population size, dispersal patterns and reproductive parameters such as birth rates and inter-birth intervals in order to understand the consequences of living in anthropogenically fragmented landscapes in this taxon. Long-term data, from several groups, is essential in order to obtain reliable data on such measures, as variation might be expected across both years and groups, and reproductive parameters require observations over several consecutive years. Owing to widespread habitat loss and fragmentation throughout its range, the remaining population of $A$. p. mexicana is now restricted to highly fragmented forested areas which has led it to be listed as critically endangered by the IUCN (Cuarón et al., 2008). Information generated by this study will be useful to understand the capacity of these primates to adapt to transformed landscapes and help develop informed projections of the conservation risk of this subspecies. dispersal patterns, reproduction and survival. Los Tuxtlas represents the northernmost limit of mantled howler monkey distribution, and is near the northern limit of the distribution of the

91 genus (Cortés-Ortiz, Rylands \& Mittermeier, 2015; Rylands et al., 2006). Previous studies

92 indicate that winter is a period of energetic stress due to the combined effect of increased 
93 thermoregulatory demands and lower food availability (Cristóbal-Azkarate et al. in prep; Dunn et

94 al., 2013), but whether this has any impact over the fitness of this howler monkey population is

95 yet to be studied. Establishing correlates between climate and life history parameters will allow

96 us to better understand the challenges howler monkeys face at the extreme limits of their

97 distribution, and the responses they develop to cope with them.

98

99

METHODS

100

101

Ethics statement

102 This study is based on observational data and there was no direct interaction with the study

103 subjects. We were granted access to the study site by local communities, landowners, and the

104 Los Tuxtlas Biosphere Reserve, part of the National Commission of Natural Protected Areas of

105 Mexico (CONANP). All research adhered to the American Society of Primatologists Principles

106 for the Ethical Treatment of Non-Human Primates and to the legal requirements of Mexico.

\section{Study species}

109 Five subspecies of mantled howler monkeys (Alouatta palliata) are currently recognised: $A$. $p$.

110 mexicana, A. p. palliata and A. p. aequatorialis, A. p. coibensis, and A. p. trabeata. These

111 subspecies are distributed from south-east Mexico to northwest Peru (Cortés-Ortiz, Rylands \&

112 Mittermeier, 2015).

113 Mantled howler monkeys are seasonally folivorous, with leaves contributing over $80 \%$

114 of food intake when fruit is scarce (Milton, 1980; Glander, 1981; Cristóbal-Azkarate \& Arroyo-

115 Rodríguez, 2007; Dunn, Cristóbal-azkarate \& Veà, 2010). This degree of folivory has been 
116 associated with their small home range size compared to other more frugivorous species (Milton

$117 \&$ May, 1976) and primates living in small home ranges are considered to be more resistant to

118 habitat fragmentation (Cowlishaw \& Dunbar, 2000).

119 Gestation lasts 6 months in mantled howler monkeys (Glander, 1980) and weaning 120 occurs at approximately 18-20 months of age (Carpenter, 1934; Clarke, 1990; Domingo-Balcells

121 \& Veà-Baró, 2009). Age of first reproduction for females is approximately 41-43 months and 122 males reach maturity at approximately 48 months of age (Glander, 1980b; Domingo-Balcells et 123 al., 2009). This species is characterized by bisexual emigration of juveniles; males typically 124 emigrate at around 22 months of age and females typically emigrate at around 33 months of age 125 (Glander, 1992). However, it has been suggested that in Los Tuxtlas juveniles may occasionally 126 emigrate as early as 14 months of age (Domingo-Balcells \& Veà-Baró, 2009). Accordingly, the 127 11-year duration of our study covers an important proportion of a howler monkey's life cycle.

128 Recent evidence indicates that secondary dispersal (individuals emigrating from groups that they 129 have previously immigrated into) also exists in mantled howler monkeys and that this can be 130 driven by the sex ratio of groups (Clarke \& Glander, 2010). Dispersal patterns can be disturbed 131 by relatively low levels of fragmentation (Chiarello \& de Melo, 2001), as howler monkeys are

132 highly arboreal and spend almost all of their time in the upper canopy, very rarely coming to the 133 ground (Mendel, 1976).

\section{Study site}

136 The Los Tuxtlas Biosphere Reserve represents the northernmost limit of tropical rainforest

137 distribution in the Americas (Guevara-Sada, Laborde \& Sánchez-Ríos, 2004). Our study site (18 $13839^{\prime} 21^{\prime \prime}-18^{\circ} 31^{\prime} 20^{\prime \prime} \mathrm{N}$ and $95^{\circ} 9^{\prime} 14^{\prime \prime}-95^{\circ} 1^{\prime} 45^{\prime \prime} \mathrm{W}$; elevation 0 - $400 \mathrm{~m}$ a.s.l) covers 
139 approximately 7, 500 hectares, and like many other regions throughout the tropics, it has suffered

140 from extensive forest loss, transformation, and fragmentation, principally as a result of cattle

141 farming (Fig. 1). This occurred predominantly between 1976-1986, and the great majority of the

142 actual forest fragments were created during this time (Cristóbal-Azkarate, 2004). Nevertheless,

143 compared to many other fragmented landscapes, it retains a relatively high level of connectivity,

144 with live fences (i.e., several strands of barbed wire held up by a line of trees), riparian

145 vegetation and isolated trees found between many fragments, and a mean distance to nearest

146 fragment of $103 \pm 172$ m (Arroyo-Rodríguez, Mandujano \& Benítez-Malvido, 2008). It also

147 contains areas of continuous forest in close proximity (less than 500m) to the fragments (Fig. 1).

148 The climate in Los Tuxtlas is warm and humid with a mean annual temperature of $25^{\circ} \mathrm{C}$

149 and rainfall of 4,900 $\mathrm{mm}$ (Soto, 2004). There is a dry season between March and May and a wet

150 season from June to February. During the wet season there is also a period of strong winds and a

151 considerable reduction in temperature between October and February (Fig. 2a). Long-term

152 records of phenological data in the region show that there are two distinct peaks in fruit

153 production: a primary peak at the end of the dry season-beginning of the rainy season (April-

154 June), and a shorter, less intense secondary peak in the wet season (August-October), while fruit

155 production abruptly falls to very low levels between November and March (Fig. 2b). The howler

156 monkeys in Los Tuxtlas respond to the reduction in temperature and fruit availability between

157 November and March by increasing their consumption of leaves and their foraging effort (Dunn,

158 Cristóbal-Azkarate \& Veà, 2010), which, in turn, has been associated to higher levels of

159 physiological stress (Dunn et al., 2013). Therefore, we refer to this period as the "period of

160 energetic stress".

161 


\section{Study groups}

163 We carried out the first census of our study site in 2000 . Of the 55 forest fragments that are

164 found in our study site, we found 21 to be inhabited with at least one howler monkey and

165 recorded a population of 316 individuals living in 43 groups (Cristóbal-Azkarate et al., 2005).

166 We began studying four of these groups intensively in 2000. Over the following 10 years, we

167 studied six more groups as part of a programme of interdisciplinary research, for a total of 10

168 groups, which provided the data for our analyses (e.g. Cristóbal-Azkarate et al., 2006, 2007;

169 Dunn, Cristóbal-azkarate \& Veà, 2010; Dunn et al., 2013). Despite the wide-ranging nature of

170 the research, we gathered basic demographic data, such as the number of individuals, age-sex

171 composition, births, deaths and migrations, over the 11-year period.

172

\section{Data collection}

174 We present demographic data from 10 groups of howler monkeys, representing 454 monthly 175 group visits, which were carried out between 2000 and 2011 (Table 1). Given that the data has

176 been pooled across several different studies, there is some discontinuity, with certain groups

177 being studied for longer and/or more frequently than others (mean $\pm \mathrm{SD}=45.1 \pm 29.7$ monthly

178 visits per group; Table 1). The study groups inhabited eight different forest fragments, which 179 varied in size, shape and connectivity (Fig. 1).

180 We identified group members by the distinguishing colour patterns on their feet and tails,

181 which are characteristic of this subspecies. We created an identity sheet for each individual as a 182 reference in the field, drawing and making notes on the distinctive features (Fig S1). Each time

183 we recorded a new individual in a group, we assigned it an age and sex using the classification 
184 system developed by Balcells and Vea (Domingo-Balcells \& Veà-Baró, 2009), which allows an

185 age range to be estimated on the basis of morphological and behavioural characteristics.

186

187 Demographic events

188 Throughout the study, we registered all demographic events in the groups, including: emigration,

189 immigration, birth and death. However, given the low probability of observing these events

190 directly, some of the events were also assumed to have occurred on the basis of changes in group

191 composition and supporting evidence.

192

193 Birth

194 We assumed a new individual had been born in a group when a new dependent infant, which was 195 strongly associated with one of the group females, was observed in a group.

196 To calculate the mean annual birth rate for each group, we determined the number of

197 births that had taken place per year for the mean number of adult females in the group. This

198 allowed us to control for the effect of the number of females on birth rate. We defined the inter-

199 birth interval (IBI) as the time that occurred between births for any given female.

200

201 Emigration

202 We assumed an individual had emigrated from a group when all of the following criteria were

203 met: 1) we had not observed the individual in the group for more than one month; 2) the last time

204 we observed the individual it showed no sign of disease or injury; and 3) the last time we

205 observed the individual it was fully weaned (unless emigrating with its mother). We also 
206 classified an individual as having emigrated if it was observed in a new group or as a solitary

207 individual.

208 When an individual emigrated from the group it was born in, we defined this as 'natal

209 emigration'. When an individual emigrated from a group that it had previously immigrated into,

210 we defined this as 'secondary emigration'.

211

212 Immigration

213 We assumed a new individual had immigrated into a group when, on first sighting, its estimated

214 age was greater than the time passed since our last visit to the group (e.g., a new individual with

215 an estimated age of 12 months was observed for the first time in a group, but the group was last

216 visited 2 months ago).

217

218 Death

219 We assumed an individual had died when at least one of the following criteria was met: 1) we

220 found the body; 2) the individual went missing while still dependent on its mother's milk and its

221 mother remained in the group; or 3) the individual went missing fully weaned, but was showing

222 serious signs of injury or disease the last time it was observed.

223

224 Disappeared

225 For some individuals it was not possible to determine with any confidence whether they had 226 emigrated or died. Therefore, we recorded these individuals as disappeared.

228 Statistical analyses 
229 For the calculation of the seasonality of demographic events, IBI and birth rates, we considered

230 only those events that were registered during periods in which the study groups were observed

231 continuously and that could be assigned to a date with a maximum error of one month. In order

232 to control for the effect that our slightly unbalanced sampling effort could have on the

233 seasonality data, we weighted the original data by dividing the frequency of events per month by

234 the number of different visits to the same group within a month (mean \pm SD average visits per

235 month $=37.6 \pm 3.1$, range $=35-42$; Table 1 ). We used these weighted values to calculate the

236 percentage of demographic events in each month.

237 We used ANOVAs to analyse the differences in annual birth rate and IBI among groups,

238 and reported eta squared $\left(\eta^{2}\right)$ as a measure of effect size (which is analogous to $\mathrm{R}^{2}$ in regression

239 analyses). Values of $\eta^{2}$ vary from 0 to 1 and values of $0.02,0.13$, and 0.26 , and can be, as a rule

240 of thumb, considered as small, medium and large effects, respectively (Cohen, 1973). We also

241 used a Student's T test to test the hypothesis that the death of a suckling offspring, $\leq 14$ months

242 of age (Domingo-Balcells \& Veà-Baró, 2009), shortens the IBI by comparing the mean IBI of

243 females with surviving and non-surviving offspring, and reported Cohen's d (Cohen, 1977) as a

244 measure of effect size. For Cohen's d effect sizes of $0.2,0.5$, and 0.8 , can be thought of as small,

245 medium and large, respectively (Cohen, 1977).

246 To test for differences in the frequency of demographic events between the season of

247 energetic stress (November - March, see above) and the rest of the year, as well as to test for

248 statistically significant differences between peaks in demographic events at certain times of year

249 compared to the rest of the year, we conducted Chi-squared $\left(X^{2}\right)$ goodness of fit tests, with

250 expected values being proportionally calculated according to the number of months used in the

251 analysis. We calculated effect sizes for Chi-square tests using Cramer's phi coefficient $(\varphi)$, 
252 whereby $0.1,0.3$, and 0.5 can be interpreted as small, medium and large effects (Cramer, 1999).

253 Furthermore, in order to account for the underlying continuity of the time variable, we also used

254 circular statistics to test for seasonality of demographic events (Batschelet, 1981). This approach

255 has several advantages over those traditionally used by primatologists to test for seasonality

256 (Janson \& Verdolin, 2005; Gogarten et al., 2014). The mean vector length ( $r$ ) obtained from

257 circular statistics is well suited as an index of seasonality, as it provides a measure of how evenly

258 events are distributed throughout the year. When events are spread evenly across months (not

259 seasonal), $r$ is close to zero and when events are highly clustered at the same time of year (highly

260 seasonal), $r$ is close to one. We tested the statistical significance of the $r$ statistic using the

261 Rayleigh test (Batschelet, 1981), which compares the data with the null hypothesis that

262 demographic events have a random distribution across months. As we used monthly data for

263 demographic events, rather than specific dates, we also used a correction factor $(c=1.0115)$

264 when calculating the $r$ statistic (Batschelet, 1981). To test for bimodal distribution in the data, we 265 also calculated $r$ by doubling the angle calculated for each demographic event (Batschelet, 1981;

266 Janson \& Verdolin, 2005; Gogarten et al., 2014).

267 We carried out analyses in R 2.13.1 (Team Development Core, 2008), testing for

268 normality in the data and considering $p<0.05$ as significant.

\section{RESULTS}

272 Overall, we observed an increase in the number of individuals in our population between 2000

273 and 2011. Most of the study groups showed little change in the number of individuals and in the

274 number of adult individuals from the start to the end of the eleven-year study period. However, 
275 two groups showed a substantial increase in number (Table 2). Migration was the principal cause 276 of change in group size and composition, followed by births, then deaths. An overview of the

277 demographic events for which we were able to determine the date with a maximum error of one 278 month is given in Table 1.

279

280 Births

281 We registered 75 births and at least two births were observed in all 10 of our groups (Tables $1 \&$ 282 2). Of these, we were able to determine the date of birth to within one month on 49 occasions. 283 The mean birth rate per group was $0.42 \pm 0.32$ births per female per year $(\mathrm{N}=39$ births; 284 Table 3). There were groups with no births in some years, while other groups had a birth rate as 285 high as 1 in some years (indicating that all females of reproductive age gave birth in that year). 286 Although mean birth rate ranged from $0.18 \pm 0.24$ to $0.56 \pm 0.40$ births per female per year 287 across groups (Table 3), we found no statistically significant differences in mean birth rate 288 among groups $\left(\mathrm{F}_{9,29}=0.57, \mathrm{p}=0.81, \eta^{2}=0.15\right)$.

The mean IBI was $21.6 \pm 13.3$ months $(\mathrm{N}=18$; Table 3$)$. Although mean IBI varied from $29011.0 \pm 4.2$ months to $39.5 \pm 24.7$ months across groups (Table 3 ), we found no statistically 291 significant difference among groups $\left(F_{4,13}=1.68, p=0.22, \eta^{2}=0.34\right)$. We observed 12 IBIs in 292 which the offspring from the first birth had survived until weaning (mean $=26.1 \pm 14.1$ months) 293 and six IBIs in which the offspring from the first birth had died before weaning (mean $=12.7 \pm$ 2944.5 months), and found a significant reduction in IBI when the first offspring had died before 295 weaning $($ mean difference $=13.42,95 \% \mathrm{CI}=3.89-22.95, \mathrm{t}=3.01, \mathrm{df}=16, \mathrm{p}=0.009, \mathrm{~d}=$ 296 1.28). 
Although we observed births throughout the whole year, births were clearly seasonal.

298 Seventy-four per cent of births occurred between October and March, with a main peak in

299 November and a smaller second peak in February (Fig. 3a \& Table 1). Accordingly, the bimodal

$300 r$ statistic was highly significant (unimodal $r=0.20, \mathrm{p}=0.14$; bimodal $r=0.43, \mathrm{p}<0.001$ ). As

301 the gestation time of howler monkeys is 6 months, and weaning occurs at approximately 18-20

302 months, these data indicate that conceptions leading to births and weaning peaked in May, after

303 the period of energetic stress. In fact, the number of conceptions leading to births was not equally

304 distributed, with fewer conceptions than expected during the period of energetic stress (10

305 conceptions between November and March) and more than expected during the rest of the year

306 (39 conceptions between April and October) $\left(X^{2}=9.38, \mathrm{df}=1, \mathrm{p}<0.005, \varphi=0.19\right)$.

307

308

\section{Emigration}

309 We recorded emigrations in all but one of our study groups, with 62 individuals emigrating from

310 groups (Tables $1 \& 2$ ). Thirty-four of these were adults (13 adult males and 21 adult females), 7

311 were sub-adults ( 2 males, 2 females, and 3 of unknown sex), 13 were juveniles and 8 were

312 infants.

313 We recorded 24 natal emigrations (52.8\% of emigrations of known origin). One by an

314 adult male, 6 by adult females, 3 by subadults, 11 by juveniles and 7 by infants. Of the 7 infants,

3154 left the group soon after the birth of a sibling and 8 left the group soon after one or more

316 individuals had immigrated into their group.

317 We recorded 22 secondary emigrations (47.8\% of emigrations of known origin).

318 Nineteen of these were adults (11 males and 8 females), 1 was a male sub-adult, 1 was a juvenile

319 and 1 was an infant that transferred to the group together with her mother, and then left with her 
320 after one month of permanence in the group. The mean time that the individuals spent in a group

321 prior to secondary transfer was $18.4 \pm 21.1$ months (range $=1-90$ months).

322 On 16 occasions, we were not able to determine whether the emigrating individuals were

323 born in the group they emigrated from or whether they had previously immigrated into the group.

324 Accordingly these emigrations were of unknown origin and were not classified as natal or

325 secondary.

326 Emigrations occurred throughout the year, but there were clear differences in emigration

327 patterns among the age-sex classes (Fig. 3b, Tables 1 \& 2). Male emigration peaked in August

328 (33.1\% of cases) and January-February (43.9\%), when more emigrations occurred than expected

$329\left(X^{2}=8.57, \mathrm{df}=1, \mathrm{p}<0.005, \varphi=0.66\right.$; and $X^{2}=8.14, \mathrm{df}=1, \mathrm{p}<0.005, \varphi=0.63$, respectively),

330 female emigration showed a very clear peak in August-September (49.6\% of cases), when more

331 emigrations occurred than expected $\left(X^{2}=14.49, \mathrm{df}=1, \mathrm{p}<0.001, \varphi=0.69\right)$, and subadult and

332 juvenile emigration showed a peak in November-December (38.9\% of cases), when more

333 emigrations happened than expected $\left(X^{2}=8.87, \mathrm{df}=1, \mathrm{p}<0.005, \varphi=0.48\right)$. However, the $r$

334 statistic for seasonality was non-significant in all cases, only trending towards significance in the

335 females (unimodal $r=0.34, \mathrm{p}=0.08$ ).

336

337 Immigration

338 We recorded immigrations in all the forest fragments that we studied and in all but one of our

339 study groups (this group was only followed for one year). We recorded 57 individuals

340 immigrating into new groups (Tables $1 \& 2$ ); 46 were adults (22 males and 24 females), 6 were

341 sub-adults ( 3 males and 3 females), 3 were juveniles and 2 were infants. Of these, we were able

342 to determine the date of immigration to within one month in 41 cases (Table 1). 
345 immigrations peaked in April-May (40.5\% of cases), when more immigrations occurred than

346 expected $\left(X^{2}=5.88, \mathrm{df}=1, \mathrm{p}<0.05, \varphi=0.39\right)$ and again in September-December $(52.2 \%)$,

347 though this was not significantly more than expected by chance. Female immigration showed a

348 clear peak from September-December (79.3\% of cases), when more immigrations occurred than

349 expected $\left(X^{2}=12.89, \mathrm{df}=1, \mathrm{p}<0.001, \varphi=0.92\right)$, and subadults and juveniles showed a peak in

350 immigration between August-September (65.3\% of cases), when more immigrations occurred

351 than expected $\left(X^{2}=12.10, \mathrm{df}=1, \mathrm{p}<0.001, \varphi=1.51\right)$. Despite these peaks in immigration, the $r$

352 statistic for seasonality was non-significant in all cases

353

354

355

356

357

358

359

360

361

362

363

364

365

\section{Deaths}

We registered 18 deaths, and at least one death was registered in eight of the 10 groups (Table 2).

Thirteen of these individuals were infants: eight were younger than four months of age, three between four and eight months, and two were 10 months of age. Of these, we only observed one death directly, when, a one-month old infant died shortly after we found it lying by its dead mother which was seemingly killed by another howler monkey (see below). On another occasion we assumed that an infant had died shortly after its mother had died and it was observed falling in a tree. We assumed one juvenile to have died having shown signs of physical weakness and struggling to keep up with the group. The remaining four deaths were all adults. We recovered the body of one female, which had several serious bite marks. Post-mortem examination by a veterinarian found the cause of death to be lung perforation, consistent, in terms of bite shape, breadth and depth, with an attack by another howler monkey (Escorcia-Quintana, personal 
366 communication). One adult male probably died after we observed it with severe open wounds

367 resulting from an attack by two immigrating males. Another adult male showed signs of

368 paralysis and lethargy before his assumed death. A further adult male showed signs of old age,

369 lack of appetite and was unable to keep up with the group.

370 We registered deaths in most months of the year, but there was a clear peak between

371 November and March when $75.3 \%$ of deaths occurred (Fig. 3d, Table 1). There were more

372 deaths than expected during the period of energetic stress $(\mathrm{N}=14)$, and fewer than expected in

373 the rest of the year $(\mathrm{N}=4)\left(X^{2}=9.66, \mathrm{df}=1, \mathrm{p}<0.005, \varphi=0.54\right)$. However, the $r$ statistic for

374 seasonality was not significant (unimodal $r=0.08, \mathrm{p}=0.89$; bimodal $r=0.25, \mathrm{p}=0.30$ ).

375

376 Disappeared

377 We were unable to interpret the history of 27 individuals from the data, which we recorded as 378 disappeared (Table 2).

379

380 DISCUSSION

381 We present data on 11 years of demographic events in 10 groups of mantled howler monkeys

382 living in an anthropogenic landscape in Mexico. Due to the discontinuous nature of our sampling

383 method, it is likely that we failed to record some events. For example, we might have missed

384 short-term dispersal events, or births followed quickly by deaths. Also it is possible that some

385 events were recorded incorrectly: e.g., when we did not observe an individual in a group for

386 more than one month, we assumed that it had migrated, but it is also possible that it had died

387 suddenly, or been killed by a predator or conspecific. However, given that the number of

388 emigrations closely matched the number of immigrations, and that no natural predators of howler 
389 390 to be reasonable.

391

392

393

394 395

monkeys remain in Los Tuxtlas (Cristóbal-Azkarate \& Dunn, 2013), we consider our assumption

While acknowledging the limitations of our study, our data suggest a dynamic population with frequent demographic change, including a large number of migrations, births and deaths. While births were distributed throughout the year, they were highly seasonal, with a clear peak between October and December and a secondary peak in February. Another study carried out in a different area of Los Tuxtlas found similar results (Carrera- Sánchez, Medel-Palacios \& Rodríguez-Luna, 2003). This suggests that the majority of conceptions that lead to births occur between April and June (Fig. 3a), coinciding with the annual peak in fruit availability and increase in ambient temperature (Figs. 2a \& 2b). Accordingly, our data suggest that the higher energetic stress between November and March may be inhibiting the reproduction of females and that the improved conditions from April to June results in an increase in fertility. Other studies have also reported that the time of conception is associated with the availability of food and temperature in howler monkeys (Kowalewski \& Zunino, 2004). This supports the idea that howler monkeys are income breeders (rather than capital breeders) and that they use energy acquired during the reproductive period for reproduction instead of stored energy (Brockman \& van Schaik, 2005; Janson \& Verdolin, 2005). Similarly, the weaning of offspring would also occur in April and May, supporting the idea that the weaning of offspring in howler monkeys occurs at times of year in which the availability of high quality food is higher and the climate is more benign (Kowalewski \& Zunino, 2004).

The mean birth rate of the study groups is within the range reported for other growing populations in the Neotropics (Table 3), which suggests that, in principle, our study population is not constrained by its reproductive output, and the IBI is also within the range previously 
412 reported for the species (Table 3). However, comparisons of birth rate and IBI across studies

413 should be made with caution, owing to differences in methods. The death of an infant

414 significantly reduced the IBI, a phenomenon also reported for other primate species (Fedigan \&

415 Rose, 1995).

416 We recorded numerous migration events, with both emigration and immigration being

417 observed in almost all of the study groups. This included the groups that inhabited a forest

418 fragment with no other groups, as they all received immigrants, and all but one were a source of

419 emigrants. This suggests that, in our study landscape, howler monkeys are able to transfer

420 between forest fragments. This behaviour has also been reported elsewhere for howler monkeys,

421 and the probability of dispersal has been negatively related to the isolation distance of the

422 fragment and positively related to the connectivity of the fragment and heterogeneity of the

423 landscape (Glander, 1992; Mandujano, Escobedo-Morales \& Palacios-silva, 2004; Estrada et al.,

424 2006; Mandujano et al., 2006; Asensio et al., 2009). Accordingly, we believe that the high levels

425 of dispersal recorded in our study population are probably related to the high level of landscape 426 connectivity.

427 The high number of migratory events that we observed is a good sign for the long-term

428 viability of the population, as transfer among forest fragments may serve to mitigate the negative

429 effects of forest fragmentation on howler monkeys, by improving access to resources and

430 promoting outbreeding. Unfortunately, we were unable to determine the exact origin and

431 destination of most migrations. Determining which groups and fragments are in migratory

432 contact with each other, in addition to identifying important dispersal routes, would allow for

433 better modeling of the dynamics of our study population and help identify priority areas for

434 conservation. This gap in our knowledge should be addressed in the future with research focused 
435 on molecular genetic methods in addition to telemetry to follow the movement of individuals in 436 the landscape.

437 Both natal and secondary emigration was common in our population. The fact that most

438 juveniles leave their natal group is well described in the literature (Glander, 1992), but it was not

439 until very recently that it was proposed that secondary dispersal may be a common and important

440 component of the reproductive strategy of mantled howler monkeys (Clarke \& Glander, 2010).

441 The fact that almost half of all emigrations in our study population were secondary dispersals

442 provides strong support for this hypothesis. While emigration was not found to be strongly

443 seasonal, males and females showed clear peaks (males in January-February and August;

444 females August-September) which preceded the peaks in immigration by less than two months

445 (Figs. 3b \& 3c), while the emigration of subadults and juveniles peaked in November, coinciding

446 with the beginning of the period of fruit scarcity and higher levels of physiological stress (Dunn

447 et al., 2013). This could suggest that the timing of adult emigration might be associated with

448 factors determining the best time for transferring to a new group (e.g., resource availability and

449 reproduction), while the emigration of subadults and juveniles might be driven by competition

450 for food. However, we cannot rule out the possibility that the January-February peak in male

451 emigration might also be associated with competition for food. Without more information on the

452 life of solitary individuals in Los Tuxtlas, including data on the duration of this period for males

453 and females, it is not possible to draw any definitive conclusions from these data.

454 Like emigration, immigration was not found to be strongly seasonal in statistical terms.

455 However, for both sexes these events were more common during the primary and secondary

456 peaks in fruit availability and consumption by howler monkeys in Los Tuxtlas (Dunn, Cristóbal-

457 azkarate \& Veà, 2010), which suggests that resident individuals may be more willing to accept 
458 immigrants during periods of relative resource abundance. Moreover, the primary peak in male

459 immigration (April-May) coincides with the time when most conceptions leading to births

460 occurred. It is not clear whether in Los Tuxtlas immigrating males achieve alpha status

461 immediately upon immigration as described in Alouatta palliata palliata in Costa Rica (Glander,

462 1980a). However, several males were observed mating with females shortly after immigration

463 (pers. communication) and, nonetheless, mantled howler males are not reported to monopolize

464 reproduction (Jones, 1995; Wang \& Milton, 2003). Therefore, the availability of fertile females

465 may be driving, at least in part, the timing of immigration of males. On the other hand, by joining

466 the group several months before the onset of the period with the highest number of conceptions

467 leading to births (April-May), the females may have more time to achieve an adequate position

468 in the group to maximise their chances for successful reproduction when the environmental

469 conditions are optimal.

470 The fact that we only recorded 3 immigrations by juveniles, but recorded 13 emigrations,

471 suggests that the mortality of juveniles may be high during these periods, and/or that

472 immigration into groups is easier for fully grown adults and juveniles may need to spend several

473 years as solitary individuals before forming a new group or joining an established group

474 (Glander, 1992). Although intense fighting has previously been reported between resident males

475 and adult male immigrants (Clarke \& Glander, 2004; Dias et al., 2010), and evidence from facial

476 scarring and injuries suggests that fighting may be common in howler monkeys in Los Tuxtlas

477 (Cristóbal-Azkarate, Dias \& Veà, 2004), we only observed one such fight during our study, and

478 apart from this occasion, we did not observe any males with injuries following an immigration

479 event. 
We registered 18 assumed deaths, which were predominantly infants, although we were unable to determine the cause of death for most of the cases. The fact that a group female was, seemingly, killed by a conspecific while carrying a 1-month-old infant is noteworthy, and may have been the result of an attempted infanticidal attack. However, this is speculative and, without more information of the context and details of the event, it is difficult to interpret. One male probably died after we observed it with severe open wounds resulting from an attack by two immigrating males. Ignoring these cases, which were seemingly the result of intraspecific aggression, deaths showed a clear pattern with $75 \%$ of total deaths, and $100 \%$ of adult deaths, occurring in the period of energetic stress. Thus, it seems that energetic constraints may be an important factor regulating the population dynamics of howler monkeys in the region. increased during the eleven-year study period (though this increase is largely due to two groups). Moreover, we found migration events to be frequent between groups and fragments, despite the isolating effects of forest fragmentation. However, the study period was short relative to the long life span and slow life-history of howler monkeys, and the fragmentation history is relatively recent in the region, meaning that group size and composition may not yet be well suited to the current environmental conditions. Only studies covering several generation-times, which incorporate indices of health, reproduction and fitness (e.g., ecophysiology, molecular genetics) in conjunction with intensive data on demographic evolution, would allow us to fully examine 499 the long-term conservation prospects of this population.

\section{ACKNOWLEDGEMENTS}


502 This paper is dedicated to the wonderful memory of our colleague Dr Joaquim Vea-Baro,

503 founder of this long-term research project, who died in February 2016. Joaquim was a passionate

504 ethologist and primatologist, whose legacy in terms of both scientific output and the training of

505 students will continue for decades to come. We are grateful to all of the field assistants and

506 researchers that, during their time in the field, have collected demographic data for our analyses:

507 Lino Mendoza, Pedro Dias, Sira Vegas-Carillo, Blanca Hervier, Norberto Asensio, Iñaki

508 Aldekoa. We also thank Ernesto Rodríguez-Luna and Rosamond Coates for their valuable

509 assistance with our research and Carmen Galán for help with Figure 1.

510

\section{BIBLIOGRAPHY}

512

513

514

515

516

517

518

519

520

521

522

523

524

525

526

527

528

529

530

531

532

533

534

Arroyo-Rodríguez V., Mandujano S., Benítez-Malvido J. 2008. Landscape attributes affecting patch occupancy by howler monkeys (Alouatta palliata mexicana) at Los Tuxtlas, Mexico. American Journal of Primatology 70:69-77. DOI: 10.1002/ajp.20458.

Asensio N., Arroyo-Rodríguez V., Dunn JC., Cristóbal-Azkarate J., Moores LJ., Barcelona U De., Tropicales CDI. 2009. Conservation value of landscape supplementation for howler monkeys living in forest patches. Biotropica 41:768-773. DOI: 10.1111/j.17447429.2009.00533.x.

Balcells C., Baró J. 2009. Developmental stages in the howler monkey, subspecies Alouatta palliata mexicana: a new classification using age-sex categories. Neotropical Primates $16: 1-8$.

Batschelet E. 1981. Circular statistics in biology. In: Academic Press, 371.

Brockman DK., van Schaik CP. 2005. Seasonality and reproductive function. In: Brockman DK, van Schaik CP eds. Seasonality in primates. Cambridge, UK: Cambridge University Press, 270-305.

Carpenter CR. 1934. A field study of the behavior and social relations of howling monkeys (Alouatta palliata). Comparative Psychology Monographs 10:1-168.

Carrera- Sánchez E., Medel-Palacios G., Rodríguez-Luna E. 2003. Population study of mantled howler monkeys (Alouatta palliata mexicana) of Agaltepec Island, Veracruz, Mexico. Neotropical Primates:176-180.

Chiarello A., de Melo F. 2001. Primate population densities and sizes in Atlantic forest remnants of northern Espirito Santo, Brazil. International Journal of Primatology 22:379-396. DOI: 10.1023/A:1010751527749.

Clarke MR. 1990. Behavioral development and socialization of infants in a free-ranging group of 
535

536

537

538

539

540

541

542

543

544

545

546

547

548

549

550

551

552

553

554

555

556

557

558

559

560

561

562

563

564

565

566

567

568

569

570

571

572

573

574

575

howling monkeys (Alouatta palliata). Folia Primatologica 54:1-15. DOI: $10.1159 / 000156422$.

Clarke MR., Crockett CM., Zucker EL., Zaldivar M. 2002. Mantled howler population of Hacienda La Pacifica, Costa Rica, between 1991 and 1998: Effects of deforestation. American Journal of Primatology 56:155-63. DOI: 10.1002/ajp.1071.

Clarke M., Glander K. 2004. Adult migration patterns of the mantled howlers of La Pacifica. American Journal of primatology 62:Suppl. 87.

Clarke MR., Glander KE. 2010. Secondary transfer of adult mantled howlers (Alouatta palliata) on Hacienda La Pacifica, Costa Rica: 1975 - 2009. Behaviour 51:241-249. DOI: 10.1007/s10329-010-0195-5.

Cohen J. 1973. Eta-squared and partial eta-squared in fixed factor anova designs. Educational and psychological measurement:107-112.

Cohen J. 1977. Statistical Power Analysis for the Behavioral Sciences. Elsevier.

Cortés-Ortiz L., Rylands AB., Mittermeier RA. 2015. The taxonomy of howler monkeys: integrating old and new knowledge from morphological and genetic studies. In: Kowalewski MM, Garber PA, Cortés-Ortiz L, Urbani B, Youlatos D eds. Howler Monkeys: Adaptive Radiation, Systematics, and Morphology. Springer, New York, 55-84. DOI: 10.1007/978-1-4939-1957-4_3.

Cowlishaw G., Dunbar RIM. 2000. Primate conservation biology. In: University Of Chicago Press, 498.

Cramer H. 1999. Mathematical methods of statistics. Princeton University Press.

Cristóbal-Azkarate J., Booth RK., Dunn JC., Vea JJ., Wasser SK. (in prep.) Combining feacal thyroid and glucocorticoids as an index of thermal and energetic load in a tropical primate. Physiology and Behavior.

Cristóbal-Azkarate J. 2004. Determinación de la capacidad de carga de un hábitat y evaluación de la capacidad de adaptación conductual y social de los monos aulladores (Alouatta palliata mexicana. Universitat de Barcelona.

Cristóbal-Azkarate J., Veà JJ., Asensio N., Rodríguez-Luna E., Vea JJ. 2005. Biogeographical and floristic predictors of the presence and abundance of mantled howlers (Alouatta palliata mexicana) in rainforest fragments at Los Tuxtlas, Mexico. American Journal of Primatology 67:209-222. DOI: 10.1002/ajp.20178.

Cristóbal-Azkarate J., Chavira R., Boeck L., Rodríguez-Luna E., Veà JJ. 2006. Testosterone levels of free-ranging resident mantled howler monkey males in relation to the number and density of solitary males: A test of the challenge Hypothesis. Hormones and Behavior 49:261-267. DOI: 10.1016/j.yhbeh.2005.07.015.

Cristóbal-Azkarate J., Chavira R., Boeck L., Rodríguez-Luna E., Veà JJ. 2007. Glucocorticoid levels in free ranging resident mantled howlers: a study of coping strategies. American Journal of Primatology 69:866-876. DOI: 10.1002/ajp.20383.

Cristóbal-Azkarate J., Arroyo-Rodríguez V. 2007. Diet and activity pattern of howler monkeys (Alouatta palliata) in Los Tuxtlas, Mexico: effects of habitat fragmentation and implications for conservation. American Journal of Primatology 69:1013-1029. DOI: 
576

577

578

579

580

581

582

583

584

585

586

587

588

589

590

591

592

593

594

595

596

597

598

599

600

601

602

603

604

605

606

607

608

609

610

611

612

613

614

615

616

617

10.1002/ajp.20420.

Cristóbal-Azkarate J., Dias PAD., Veà JJ. 2004. Causes of intraspecific aggression in Alouatta palliata mexicana: Evidence from injuries, demography, and habitat. International Journal of Primatology 25:939-953. DOI: 10.1023/B:IJOP.0000029130.10312.63.

Cristóbal-Azkarate J., Dunn JC. 2013. Lessons from Los Tuxtlas: 30 years of research into primates in fragments. In: Marsh LK, Chapman CA eds. Primates in fragments: complexity and resilience. New York, NY: Springer, New York, 75-88. DOI: 10.1007/978-1-46148839-2.

Crockett CM., Rudran R. 1987. Red howler monkey birth data II: Interannual, habitat, and sex comparisons. American Journal of Primatology 13:369-384. DOI: 10.1002/ajp.1350130403.

Cuarón A., Shedden A., Rodríguez-Luna E., de Grammont PC., Link A. 2008. IUCN Red List of Threatened Species. Version 2012.2<www.iucnredlist.org>. Downloaded on 05 April 2013.

Dias PAD., Rangel-Negrin A., Veà JJ., Canales-Espinosa D. 2010. Coalitions and male-male behavior in Alouatta palliata. Primates; journal of primatology 51:91-4. DOI: 10.1007/s10329-009-0170-1.

Dias PAD., Coyohua-Fuentes A., Canales-Espinosa D., Rangel-Negrin A. 2015. Group Structure and Dynamics in Black Howlers (Alouatta pigra): A 7-year Perspective. International Journal of Primatology 36:311-331. DOI: 10.1007/s10764-015-9827-3.

Domingo-Balcells C., Veà J., Veà-Baró JJ., Balcells C., Baró J., Veà J., Veà-Baró JJ., Balcells C., Baró J. 2009. Developmental stages in the howler monkey, subspecies Alouatta palliata mexicana: A new classification using age-sex categories. Neotropical Primates 16:1-8. DOI: $10.1896 / 044.016 .0101$.

Domingo-Balcells C., Veà-Baró JJ. 2009. Developmental stages in the howler monkey, subspecies Alouatta palliata mexicana: A new classification using age-sex categories. Neotropical Primates 16:1-8. DOI: 10.1896/044.016.0101.

Dunn JC., Cristóbal-Azkarate J., Schulte-Herbrüggen B., Chavira R., Veà JJ., Vea JJ. 2013. Travel time predicts fecal glucocorticoid levels in free-ranging howlers (Alouatta palliata). International Journal of Primatology 34:246-259. DOI: 10.1007/s10764-013-9657-0.

Dunn JC., Cristóbal-azkarate J., Veà JJ. 2010. Seasonal variations in the diet and feeding effort of two groups of howlers in different sized forest fragments. International Journal of Primatology 31:887-903. DOI: 10.1007/s10764-010-9436-0.

Estrada A., Sáenz-Méndez, Joel Cris.; Harvey CA., Naranjo E., Muñoz-Guerrero, Diego Rosales-Meda A., Marleny M. 2006. Primates in agroecosystems: conservation value of some agricultural practices in Mesoamerican landscapes. In: Estrada A, Garber PA, Pavelka MSM, Luecke L eds. New perspectives in the study of Mesoamerican primates: Distribution, ecology, behavior, and conservation. Springer, New York, 437-470.

Estrada A., Coates-Estrada R. 1996. Tropical rain forest fragmentation and wild populations of primates at Los Tuxtlas, Mexico. International Journal of Primatology 17:759-783. DOI: 10.1007/BF02735263.

Fedigan LM., Rose LM. 1995. Interbirth interval in three sympatric species of neotropical 
618

619

620

621

622

623

624

625

626

627

628

629

630

631

632

633

634

635

636

637

638

639

640

641

642

643

644

645

646

647

648

649

650

651

652

653

654

655

656

657

658

monkey. American journal of primatology 37:9-24. DOI: 10.1002/ajp.1350370103.

Glander KE. 1980a. Reproduction and population growth in free-ranging mantled howling monkeys. American Journal of Physical Anthropology 53:25-36.

Glander KE. 1980b. Reproduction and Population Growth in Free-Ranging Mantled Howling Monkeys. American Journal of Physical Anthropology 53:25-36. DOI: 10.1002/ajpa.1330530106.

Glander KE. 1981. Feeding patterns in mantled howling monkeys. In: Kamil AC, Darsent TD eds. Foaging behavior: Ecological, ethological and psychological approaches. New York: Garland Press, 231-259.

Glander KE. 1992. Dispersal patterns in Costa Rican mantled howling monkeys. International Journal of Primatology 13:415-436.

Gogarten JF., Brown LM., Chapman CA., Cords M., Doran- D., Fedigan LM., Grine FE., Perry S., Pusey AE. 2014. Seasonal mortality patterns in non-human primates: implications for variation in selection pressures across environments. 66:3252-3266. DOI: 10.1111/j.15585646.2012.01668.x.SEASONAL.

Guevara-Sada S., Laborde J., Sánchez-Ríos G. 2004. Los Tuxtlas: El paisaje de la sierra. In: Instituto de Ecología A. C. and European Union, 287.

Janson CH., Verdolin J. 2005. Seasonality of primate births in relation to climate. In: Brockman DK, van Schaik CP eds. Seasonality in primates: studies of living and extinct human and non-human primates. Cambridge, UK: Cambridge University Press, 307-350.

Jones CB. 1995. Howler subgroups as homeostatic mechanisms in disturbed habitats. Neotropical Primates 3:7-8.

Kappeler P., Watts DP. 2012. Long term field studies of primates. In: Springer, New York, 460.

Kowalewski M., Zunino GE. 2004. Birth seasonality in Alouatta caraya in Northern Argentina. International Journal of Primatology 25:383-400. DOI: 10.1023/B:IJOP.0000019158.45628.4a.

Mandujano S., Escobedo-Morales., L. A., Palacios-Silva R., Arroyo-Rodríguez V., RodriguezToledo EM. 2006. A metapopulation approach to conserving the howler monkeys in highly altered landscape in Mexico. In: Estrada A, Garber P, Pavelka MSM, Luecke L eds. New perspectives in the study of Mesoamerican primates: Distribution, ecology, behavior, and conservation. Springer, New York, 513-538.

Mandujano S., Escobedo-Morales LA., Palacios-silva R. 2004. Movements of Alouatta Palliata among forest fragments in Los Tuxtlas, Mexico. Neotropical Primates 12:126-131.

Mendel F. 1976. Postural and locomotor behavior of Alouatta palliata on various substrates. Folia Primatologica:36-53. DOI: 10.1159/000155728.

Milton K. 1980. The foraging strategy of howler monkeys: A study of primate economics. In: New York: Columbia University Press, 165.

Milton K. 1982. Dietary quality and demographic regulation in a howler monkey population. In: Leigh E, Rands SA, Windsor D eds. The ecology of a tropical forest: Seasonal rhythms and long-term changes. Washington, DC, 273-289.

Milton K. 1990. Annual mortality patterns of a mammal community in central Panama. Journal 
659

660

661

662

663

664

665

666

667

668

669

670

671

672

673

674

675

676

677

678

679

680

681

682

683

684

685

686

687

688

689

690

691

692

693

694

695

696

697

of Tropical Ecology 6:493-499. DOI: 10.1017/S0266467400004909.

Milton K. 1996. Effects of bot fly (Alouattamyia baeri) parasitism on a free-ranging howler monkey (Alouatta palliata) population in Panama. Journal of Zoology 239:39-63. DOI: 10.1111/j.1469-7998.1996.tb05435.x.

Milton K., May ML. 1976. Body weight, diet and home range area in primates. Nature 259:459462. DOI: $10.1038 / 259459 \mathrm{a} 0$.

Rudran R., Fernandez-Duque E. 2003. Demographic changes over thirty years in a red howler population in Venezuela. International Journal of Primatology 24:925-947. DOI: 10.1023/A:1026241625910.

Rylands AB., Groves CP., Mittermeier RA., Cortés-Ortiz L., Hines J. 2006. Taxonomy and distribution of Mesoamerican primates. In: Garber PA, Pavelka MSM, Luecke L eds. New perspective in Mesoamerican primates: Distribution, ecology, behaviour, and conservation. Springer, New York, 29-79.

Soto M. 2004. El Clima. In: Laborde J, Sánchez G eds. Los Tuxtlas: El paisaje de la Sierra. Instituto de Ecología A. C. and European Union, 195-200.

Strier KB., Mendes SL., Santos RR. 2001. Timing of births in sympatric brown howler monkeys (Alouatta fusca clamitans) and northern muriquis (Brachyteles arachnoides hypoxanthus). American journal of primatology 55:87-100. DOI: 10.1002/ajp.1042.

Team Development Core R. 2008. R: A language and environment for statistical computing. R Foundation for Statistical Computing, Vienna, Austria.

Wang E., Milton K. 2003. Intragroup social relationship of male Alouatta palliata on Barro Colorado Island, Republic of Panama. International Journal of Primatology 24:1227-1243.

Zucker EL., Clarke MR. 2003. Longitudinal assessment of immature-to-adult ratios in two groups of Costa Rican Alouatta palliata. International Journal of Primatology 24:87-101. DOI: $10.1023 / A: 1021498529202$.

Zunino GE., Kowalewski MM., Oklander LI., González V. 2007. Habitat Fragmentation and Population Size of the Black and Gold Howler Monkey (Alouatta caraya). American Journal of Primatology 69:966-975.

(1)

(1)




\section{FIGURE LEGENDS}

713

714 Figure 1. Ortophoto obtained from INEGI (freely available from http://www.inegi.org.mx) of

715 our 7,500 ha study area in the Los Tuxtlas Biosphere Reserve, Veracruz, Mexico, indicating the

716 forest fragments inhabited by the 10 study groups. Areas in dark green represent forest, light

717 green pasture and black the sea. Note that the RH fragment has recently connected to continuous

718 forest through regrowth of secondary vegetation, but during the period that this group was

719 studied there was no such connection.

721 Figure 2. A) Monthly average minimum and maximum temperature and rainfall in the study

722 area for the study period; and B) Plant phenology in Los Tuxtlas adapted from Dunn, Cristóbal723 azkarate \& Veà (2010) showing percentage of fresh fruit biomass each month. 
725 Figure 3. Seasonality of demographic events $(A=$ birth, $B=$ emigration, $C=$ immigration, $D=$ 726 natural death, i.e., not associated with aggression) for 10 groups of mantled howler monkeys in

727 the Los Tuxtlas Biosphere Reserve, Mexico. Dispersal events of infants are not considered

728 because they always occurred in the company of their mothers. Values are weighted by dividing

729 the frequency of demographic events by the number of observations conducted each month.

730

731

732

733

734

735 
736 Table 1. Sampling chart of monthly visits to 10 groups of mantled howler monkeys in Los Tuxtlas, Mexico, between 2000 and 2011. 737 Months with at least one visit to a group are shown in dark grey. Detailed demographic data are also provided for all events for which 738 we were able to determine the date with a maximum error of one month.

\begin{tabular}{|c|c|c|c|c|c|c|c|c|c|c|c|c|c|}
\hline \multirow[t]{2}{*}{$\overline{\text { Group }}$} & \multirow[t]{2}{*}{ Year } & \multicolumn{12}{|c|}{ Month } \\
\hline & & January & February & March & April & May & June & July & August & September & October & November & December \\
\hline \multirow[t]{11}{*}{$\overline{\mathrm{MT}(1)}$} & 2000 & & & & & & & & & & & & \\
\hline & 2001 & & & & & & & & & & & & \\
\hline & 2002 & & & $3 \mathrm{~F} \downarrow$ & & & & & & & & & \\
\hline & 2003 & & & & & $1 \mathrm{SF} \downarrow$ & & & & & $1 *$ & $2 \mathrm{M} \downarrow 1 \mathrm{~J} \uparrow$ & 1I罗 \\
\hline & 2004 & & & & & & & & & & & $2 * 1 \mathrm{~S} 1 \mathrm{~J} \uparrow$ & $2 * 1 \mathrm{M}$ \\
\hline & 2005 & & 1I罾 $1 *$ & & & & $1 \mathrm{M} \downarrow$ & $1 *$ & $2 \mathrm{M} 4 \mathrm{~F} 1 \mathrm{~J} 4 \mathrm{I} \uparrow$ & & & $1 \mathrm{~F} \downarrow$ & \\
\hline & 2007 & & & & & & & & & & & & \\
\hline & 2008 & $1 *$ & & & & & $1 *$ & & & & & & \\
\hline & 2009 & & & & & $2 \mathrm{M} \downarrow$ & & & & $3 F 2 J 1 I \downarrow 2 M 2 F 1 / \uparrow$ & & & \\
\hline & 2010 & & $2 *$ & & $4 \mathrm{M} \downarrow$ & & & $1 \mathrm{~J} \uparrow$ & & & $1 \mathrm{M} 1 \mathrm{~J} \uparrow$ & $\overline{1 \mathrm{M} \downarrow}$ & \\
\hline & 2011 & $2 \mathrm{M} \uparrow$ & $1 \mathrm{M} \uparrow$ & & & & & & & & & & \\
\hline \multirow[t]{6}{*}{$\overline{\mathrm{MT}(2)}$} & 2000 & & & & & & & & & & & & \\
\hline & 2007 & & & & & & & & & & & & \\
\hline & 2008 & & & & & & & & & & & & \\
\hline & 2009 & & $1 *$ & & & $1 \mathrm{M} \downarrow 2 \mathrm{~F} \uparrow$ & $1 *$ & & & $3 \mathrm{M} 1 \mathrm{~F} \downarrow 2 \mathrm{~F} 1 \mathrm{SM} 11 \uparrow$ & & $2 \mathrm{~F} \downarrow 11^{*}$ & \\
\hline & 2010 & $1 \mathrm{M} \uparrow$ & & $2 * 1 \mathrm{~F} 1 \mathrm{I}$ & $1 * 1 \mathrm{SF} \uparrow$ & $1 \mathrm{SF} \uparrow$ & 1I是 & & $1 \mathrm{M} 1 \mathrm{~F} \uparrow$ & & & & 3* \\
\hline & 2011 & & & & & & & & & & & & \\
\hline \multirow[t]{11}{*}{$\overline{\mathrm{RC} 3}$} & 2000 & & & & & & & & & & & & \\
\hline & 2002 & & & & & & & & & & & & \\
\hline & 2003 & & & & & & & & & & & & \\
\hline & 2004 & & & & & & & & $1 *$ & $1 \mathrm{~J}_{\mathrm{S}}^{\mathrm{S}}$ & & $1 *$ & \\
\hline & 2005 & & $1 \mathrm{I}^{\mathrm{9}}$ & & & & & & & & & & \\
\hline & 2006 & & & $1 \mathrm{SF} \downarrow$ & & & & $1 *$ & $\overline{1 S M \downarrow}$ & & & $1 *$ & \\
\hline & 2007 & & & & 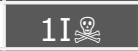 & & & & & & & & \\
\hline & 2008 & & $1 *$ & & & & & & & & $1 \mathrm{~F} \uparrow$ & $1 *$ & \\
\hline & 2009 & & & & & & & & & $1 *$ & $1 \mathrm{~F} \downarrow$ & $\overline{1 S M \downarrow}$ & $1 \mathrm{~F} \uparrow$ \\
\hline & 2010 & $1 \mathrm{~J} \uparrow$ & 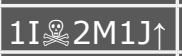 & & & & & & $\overline{1 \mathrm{M} \uparrow}$ & & $2 *$ & & \\
\hline & 2011 & & & & & & & & & & & & \\
\hline$\overline{2 \mathrm{AB}}$ & 2001 & & & & & & & & & & & & \\
\hline
\end{tabular}




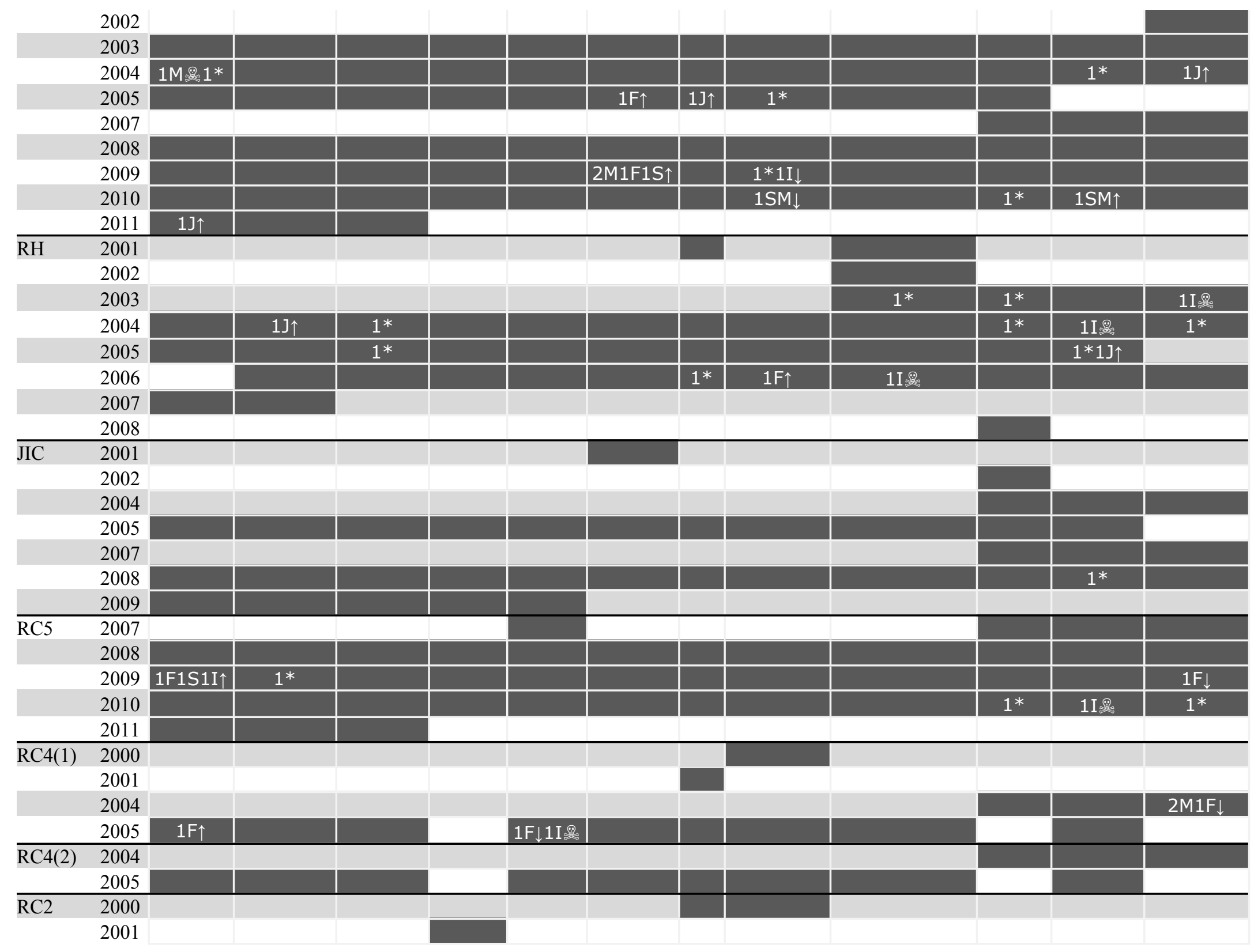


* = Birth, $\downarrow=$ immigration, $\uparrow=$ emigration, $=$ death, $\mathrm{M}=$ Adult male, $\mathrm{F}=$ Adult female, $\mathrm{S}=$ Sub-adult $(\mathrm{SM}=\mathrm{Subadult}$ male; SF $=$

741 Subadult female), $\mathrm{J}=$ Juvenile, $\mathrm{I}=$ Infant

742

754 Table 2. Demographic data from 10 groups of mantled howler monkeys in Los Tuxtlas, Mexico, between 2000 and 2011

\begin{tabular}{|c|c|c|c|c|c|c|c|c|c|c|c|c|c|}
\hline Group & $\begin{array}{c}\text { Fragment } \\
\text { size (ha) }\end{array}$ & $\begin{array}{l}\text { Study } \\
\text { Period }\end{array}$ & $\begin{array}{c}\text { Adults } \\
\text { Start }\end{array}$ & $\begin{array}{l}\text { Total } \\
\text { Start }\end{array}$ & Birth & Emigration & Immigration & Death & Disappeared & $\begin{array}{c}\text { Adults } \\
\text { end }\end{array}$ & $\begin{array}{c}\text { Total } \\
\text { end }\end{array}$ & $\begin{array}{c}\text { Adult } \\
\text { change }\end{array}$ & $\begin{array}{c}\text { Total } \\
\text { change }\end{array}$ \\
\hline
\end{tabular}




\begin{tabular}{lcccccccccccccc}
\hline MT (1) & 63.8 & $2000-2011$ & 2 & 2 & 16 & 23 & 24 & 3 & 0 & 11 & 16 & 9 & 14 \\
MT (2) & 63.8 & $2000-2011$ & 13 & 18 & 13 & 12 & 12 & 3 & 10 & 11 & 18 & -2 & 0 \\
RC3 & 7.2 & $2000-2011$ & 5 & 6 & 10 & 7 & 5 & 4 & 4 & 4 & 6 & -1 & 0 \\
2AB & 3.6 & $2001-2011$ & 5 & 5 & 8 & 9 & 4 & 1 & 2 & 3 & 5 & -2 & 0 \\
JC & 6.9 & $2001-2011$ & 2 & 2 & 3 & 0 & 4 & 0 & 0 & 7 & 9 & 5 & 7 \\
RH & 244 & $2001-2011$ & 5 & 6 & 12 & 3 & 1 & 3 & 4 & 6 & 9 & 1 & 3 \\
RC5 & 5.9 & $2007-2011$ & 3 & 4 & 3 & 3 & 1 & 1 & 0 & 3 & 4 & 0 & 0 \\
RC2 & 5.3 & $2004-2005$ & 11 & 12 & 5 & 3 & 2 & 2 & 0 & 10 & 14 & -1 & 2 \\
RC4 (1) & 17.5 & $2004-2005$ & 6 & 8 & 2 & 1 & 4 & 0 & 7 & 5 & 5 & -1 & -3 \\
RC4 (2) & 17.5 & $2004-2005$ & 5 & 5 & 3 & 1 & 0 & 1 & 0 & 5 & 6 & 0 & 1 \\
TOTAL & & $\mathbf{2 0 0 0 - 2 0 1 1}$ & $\mathbf{5 7}$ & $\mathbf{6 8}$ & $\mathbf{7 5}$ & $\mathbf{6 2}$ & $\mathbf{5 7}$ & $\mathbf{1 8}$ & $\mathbf{2 7}$ & $\mathbf{6 5}$ & $\mathbf{9 2}$ & $\mathbf{8}$ & $\mathbf{2 4}$ \\
\hline
\end{tabular}

Table 3. Mean birth rate and inter-birth interval for 10 groups of mantled howler monkeys in Los Tuxtlas, Mexico, between 2000 and 764 2010, as well as other studies of howler monkeys in the Neotropics. See methods for details of how these parameters were calculated.

\begin{tabular}{|c|c|c|c|c|c|c|c|c|c|c|}
\hline \multirow[b]{2}{*}{ Study } & \multirow[b]{2}{*}{ Taxon } & \multirow[b]{2}{*}{ Group } & \multicolumn{4}{|c|}{ Mean Birth Rate (births per female per year) } & \multicolumn{4}{|c|}{ Inter-birth interval (IBI) (months) } \\
\hline & & & $\begin{array}{c}\text { Mean } \pm \\
\text { SD }\end{array}$ & CI $(95 \%)$ & $\begin{array}{c}\mathrm{N} \\
\text { (years) }\end{array}$ & Range & Mean \pm SD & CI $(95 \%)$ & $\begin{array}{c}\mathrm{N} \\
\text { (cases) }\end{array}$ & Range \\
\hline
\end{tabular}




\begin{tabular}{|c|c|c|c|c|c|c|c|c|c|c|}
\hline Present Study & A.p. mexicana & MT (1) & $0.36 \pm 0.26$ & $0.08 / 0.63$ & 6 & $0.00-0.80$ & $11.0 \pm 4.2$ & $-27.1 / 49.1$ & 2 & $8-14$ \\
\hline Present Study & A.p. mexicana & MT (2) & $0.50 \pm 0.25$ & $-1.74 / 2.74$ & 2 & $0.32-0.68$ & $20.6 \pm 9.9$ & $8.3 / 32.9$ & 5 & $8-35$ \\
\hline Present Study & A.p. mexicana & $\mathrm{RC} 3$ & $0.56 \pm 0.40$ & $0.17 / 0.97$ & 7 & $0.00-1.00$ & $23.33 \pm 13.5$ & $9.1 / 37.5$ & 6 & $13-50$ \\
\hline Present Study & A.p. mexicana & $2 \mathrm{AB}$ & $0.47 \pm 0.32$ & $0.13 / 0.81$ & 6 & $0.00-1.00$ & $39.5 \pm 24.7$ & $-182.9 / 261.9$ & 2 & $22-57$ \\
\hline Present Study & A.p. mexicana & JIC & $0.18 \pm 0.24$ & $-0.2 / 0.55$ & 4 & $0.00-0.50$ & - & - & - & - \\
\hline Present Study & A. p. mexicana & $\mathrm{RH}$ & $0.52 \pm 0.17$ & $0.25 / 0.79$ & 4 & $0.33-0.75$ & $15 \pm 4.3$ & $4.2 / 25.8$ & 3 & $12-20$ \\
\hline Present Study & A. p. mexicana & $\mathrm{RC} 5$ & $0.25 \pm 0.35$ & $-2.93 / 3.42$ & 2 & $0.00-0.50$ & - & - & - & - \\
\hline Present Study & A. p. mexicana & $\mathrm{RC} 2$ & $0.35 \pm 0.33$ & $-2.65 / 3.35$ & 2 & $0.11-0.58$ & - & - & - & - \\
\hline Present Study & A.p. mexicana & $\mathrm{RC} 4(1)$ & $0.33 \pm 0.58$ & $-1.1 / 1.77$ & 3 & $0.00-1.00$ & - & - & - & - \\
\hline Present Study & A.p. mexicana & $\mathrm{RC} 4(2)$ & $0.33 \pm 0.33$ & $-0.49 / 1.16$ & 3 & $0.00-0.67$ & - & - & - & - \\
\hline Total & & - & $0.42 \pm 0.32$ & $0.3 / 0.51$ & 39 & $0.00-1.00$ & $21.6 \pm 13.3$ & $15.0 / 28.2$ & 18 & $8-57$ \\
\hline $\begin{array}{l}\text { Cortés Ortiz et al., } \\
1994\end{array}$ & A.p. mexicana & - & 0.62 & - & 5 & - & 15.79 & - & 19 & $10-21$ \\
\hline $\begin{array}{l}\text { Carrera- Sánchez, } \\
\text { Medel-Palacios \& } \\
\text { Rodríguez-Luna, } 2003\end{array}$ & A.p. mexicana & - & $\approx 0.5$ & - & 14 & $0.25-1.00$ & 20.4 & - & 20 & $8-50$ \\
\hline $\begin{array}{l}\text { Arroyo-Rodríguez, } \\
\text { Asensio \& Cristóbal- } \\
\text { Azkarate, } 2008\end{array}$ & A.p. mexicana & - & - & - & - & - & $25.0 \pm 3.0$ & - & 4 & $23-29$ \\
\hline Glander, 1980 & A. p. palliata & - & 0.22 & - & 7 & $0.07-0.40$ & $22.5 \pm 0.6$ & - & 16 & $18-25$ \\
\hline Fedigan \& Rose, 1995 & A. p. palliata & - & $\approx 0.5$ & - & 8 & $0.00-1.00$ & 19.9 & - & 24 & $9-40$ \\
\hline Milton, 1982 & $\begin{array}{l}\text { A. } p \text {. } \\
\text { aequatorialis }\end{array}$ & - & - & - & - & - & 17 & - & 3 & - \\
\hline $\begin{array}{l}\text { Crockett \& Rudran, } \\
1987\end{array}$ & A. arctoidea & - & 0.68 & - & 8 & $0.55-0.88$ & $17.4 \pm 4.5$ & - & 135 & $10-35$ \\
\hline $\begin{array}{l}\text { Strier, Mendes \& } \\
\text { Santos, } 2001\end{array}$ & A. guariba & - & - & - & - & - & $22.8 \pm 6.6$ & - & 12 & $11-38$ \\
\hline Rumiz, 1990 & A. caraya & - & 0.89 & - & 4 & - & $15.9 \pm 3.7$ & - & 30 & $12-22$ \\
\hline Horwich et al., 2001 & A. pigra & - & - & - & - & - & 19.4 & - & 64 & $10-35$ \\
\hline
\end{tabular}

\section{Figure 1.}




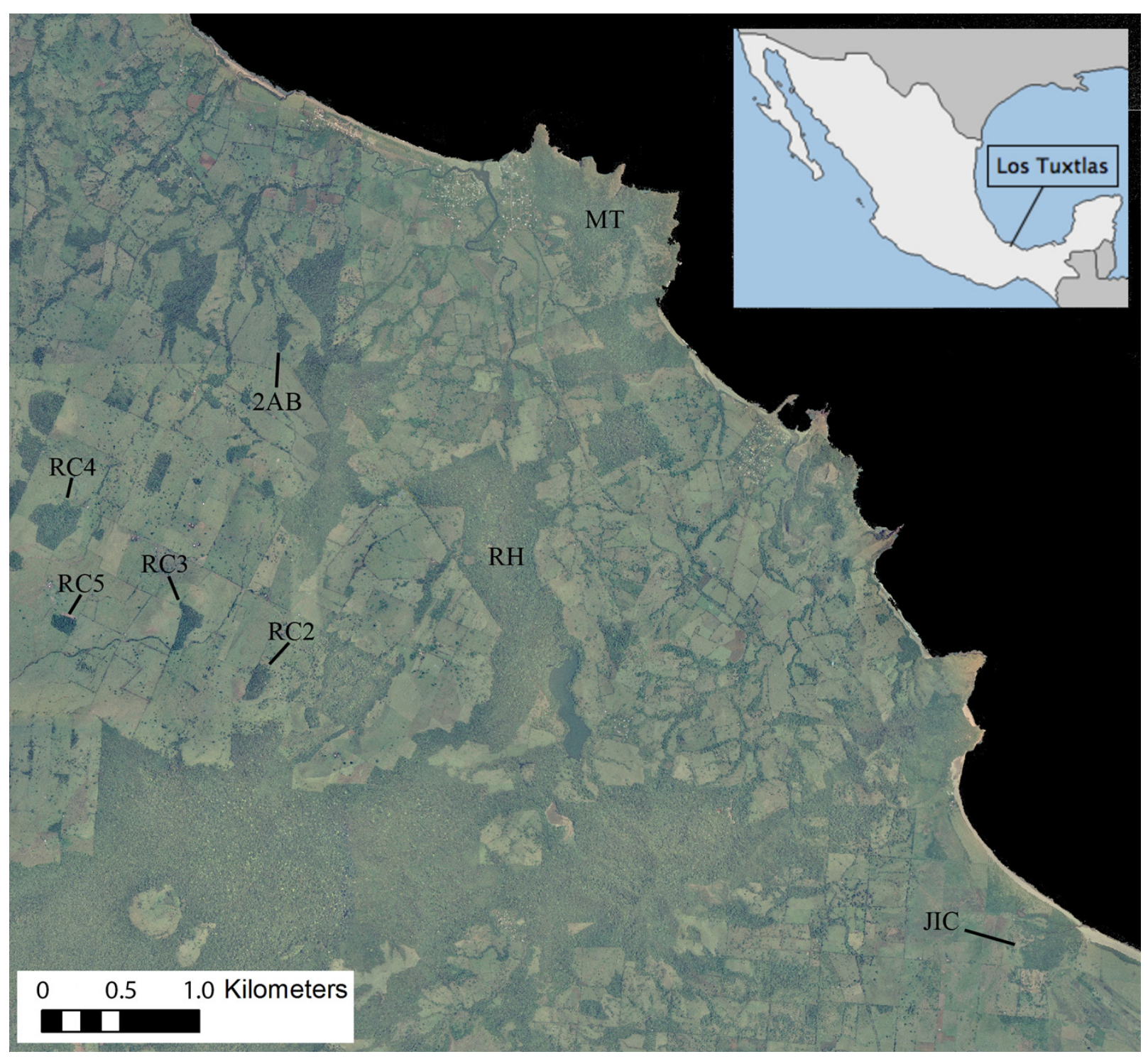

Figure 2. 

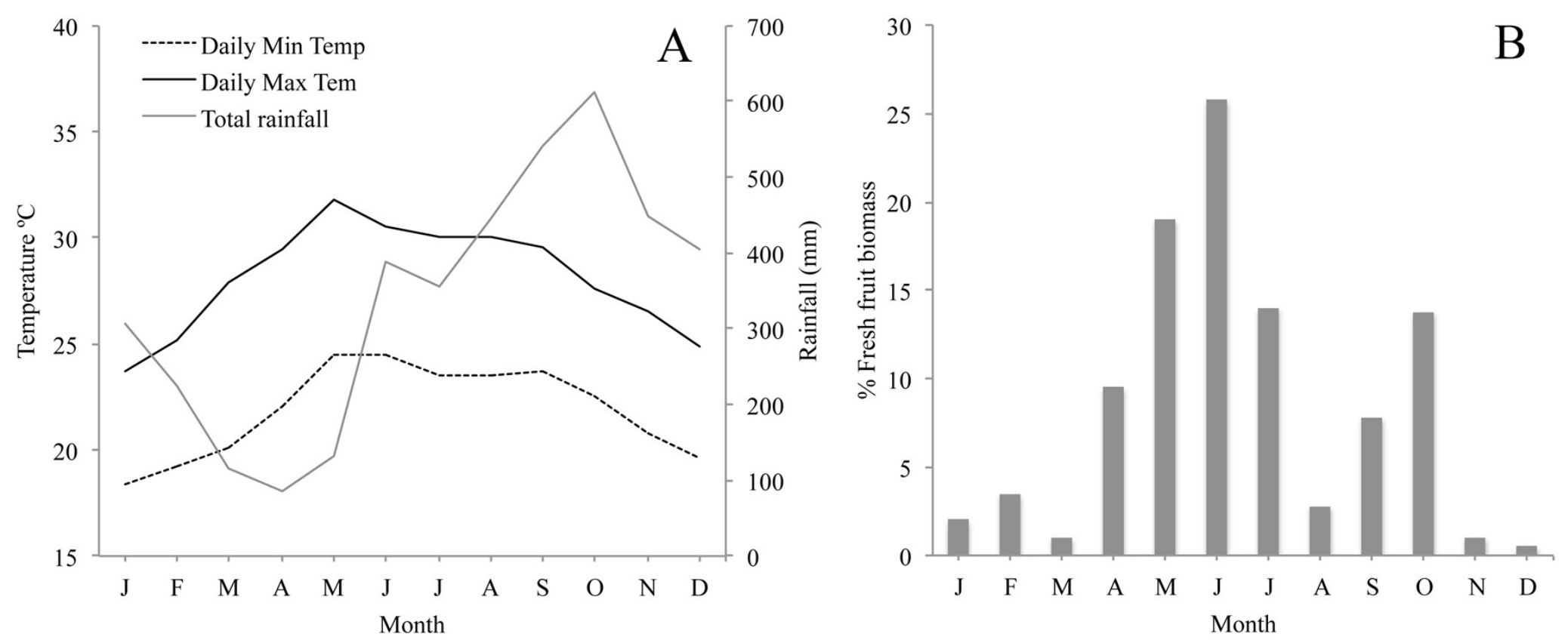

Figure 3. 

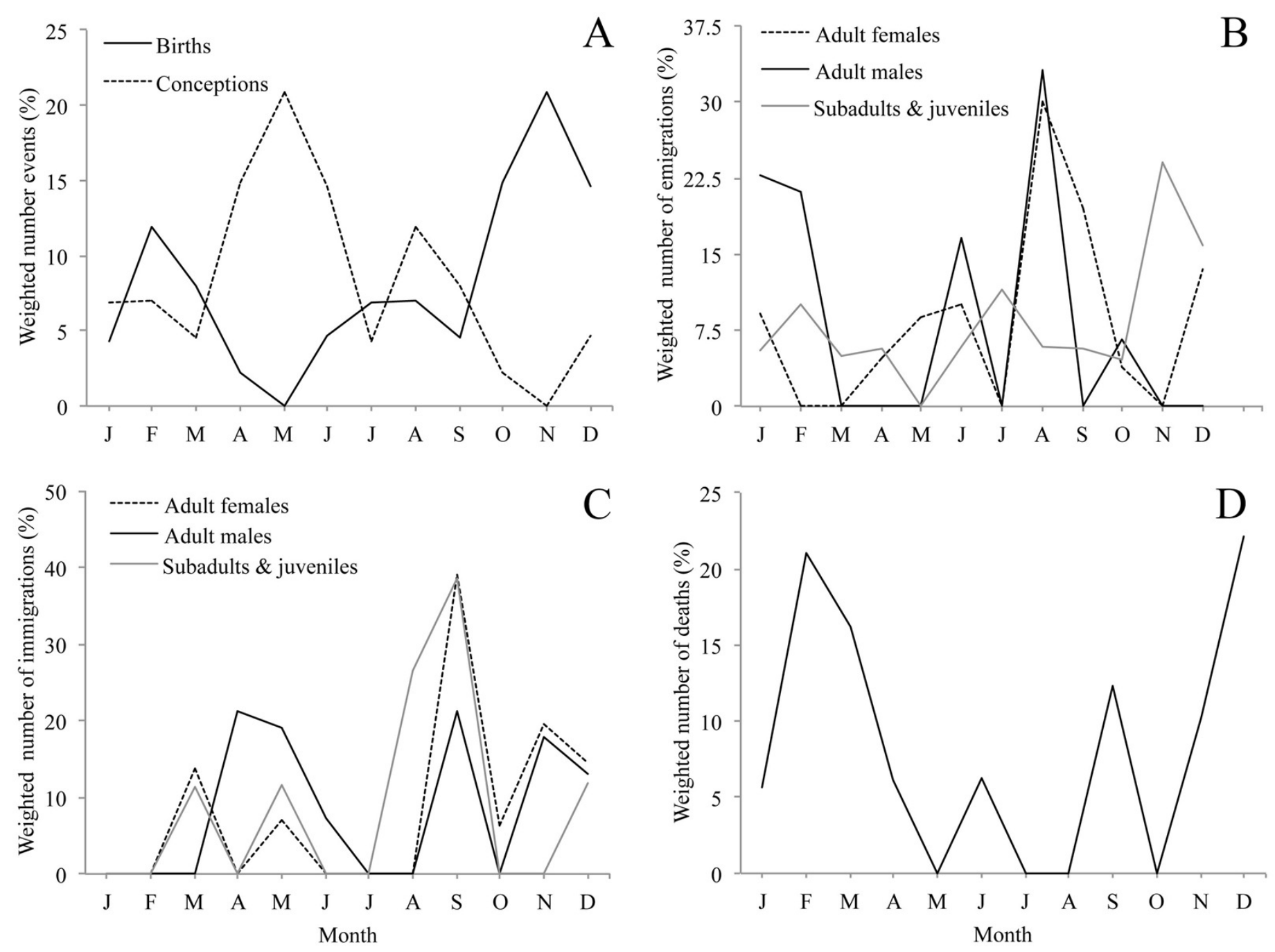